\title{
Intake, Nutrient Digestibility and Production Performance of Pesisir Cattle Fed Tithonia diversifolia and Calliandra calothyrsus-Based Rations with Different Protein and Energy Ratios
}

\author{
Roni Pazla*, Adrizal, Riesi Sriagtula
}

Faculty of Animal Science, Andalas University, Campus Unand Limau Manis Padang, Postal Code 25163.

\begin{abstract}
The productivity of Pesisir cattle is influenced by the protein-energy ratio in the feed. The purpose of this study was to determine the ratio of crude protein (CP) and total digestible nutrients (TDN) inefficient feed for production in Pesisir cattle, by looking at intake, nutrient digestibility, and production performance. Four male Pesisir cattle with an average initial body weight of $118.13 \pm 13.13 \mathrm{~kg}$, were designed with a latin square design into 4 feed treatments: treatment T1 (CP 14.45\% and TDN 57.53\%), treatment T2 (CP 14.08\% and TDN 57.80\%), treatment T3 (CP 13.38\% and TDN 58.12\%) and treatment T4 (CP 12.59\% and TDN 58.56\%). Data were analyzed by using analysis of variance. The results showed that there was an increase in intake, nutrient digestibility, and production performance in cattle that got a ratio of CP $13.38 \%$ and TDN $58.12 \%$ ( $\mathrm{C}$ treatment $)(\mathrm{P}<0.05)$. The lowest intake was found in treatment $\mathrm{T} 4(\mathrm{P}<0.05)$ but the lowest nutrient digestibility and production performance were found in treatment T1 $(\mathrm{P}<0.05)$. The study concludes that the ratio of CP and TDN could increase intake, feed digestibility, and production performance of Pesisir cattle with $13.38 \%: 58.12 \%$.
\end{abstract}

Keywords | Calliandra calothyrsus, Crude protein, Pesisir cattle, Total digestible nutrient, Tithonia diversifolia

\author{
Received | April 13, 2021; Accepted | June 30, 2021; Published | August 15, 2021 \\ *Correspondence | Roni Pazla, Faculty of Animal Science, Andalas University, Campus Unand Limau Manis Padang, Postal Code 25163; Email: ronipazla@ \\ ansci.unand.ac.id \\ Citation | Pazla R, Adrizal, Sriagtula R (2021). Intake, nutrient digestibility and production performance of pesisir cattle fed Tithonia diversifolia and Calliandra \\ calothyrsus-based rations with different protein and energy ratios. Adv. Anim. Vet. Sci. 9(10): 1608-1615. \\ DOI | http://dx.doi.org/10.17582/journal.aavs/2021/9.10.1608.1615 \\ ISSN (Online) | 2307-8316; ISSN (Print) | 2309-3331
}

Copyright $(92021$ Lukkananukool et al. This is an open access article distributed under the Creative Commons Attribution License, which permits unrestricted use, distribution, and reproduction in any medium, provided the original work is properly cited.

\section{INTRODUCTION}

$\mathrm{C}$ attles as a source of animal protein play an important role in supporting national food security (Basyar, 2021). Beef is still the community's choice because of their complete nutritional value, like lipids, proteins with high biological value, trace elements, and vitamins (Pighin et al., 2016). One of the native Indonesian cattle found in the Southern Pesisir district of West Sumatra province is Pesisir cattle (Hartatik et al., 2018). Pesisir cattle include five native Indonesian cattle germplasm after Bali cow, Aceh cow, Sumbawa, and Madura cow. Pesisir cattle can adapt to conditions in a coastal environment that is poor of forage. The carcass percentage of Pesisir cattle is 50.6\%, which is higher than the carcass percentage of buffalo (39.3\%), Ongole crossbred cattle (45\%), Madura cattle
(47.2\%), and Ongole cattle (48.8\%), however it is slightly lower than the percentage of Bali cattle (56.9\%) (Hendri, 2013). A high percentage of carcass indicates the ability to convert low-quality feed into meat. The average daily gain (ADG) of Pesisir cattle is still low, this is due to the quality of feed consumed by Pesisir cattle only comes from native grass.

Tithonia (Tithonia diversifolia) and calliandra (Calliandra calothyrsus) are foraging that have the potential to be used as food for ruminants (Trisnadewi et al., 2016; Arief et al., 2018, 2019; Jamarun et al., 2019). Apart from their abundant availability, these two plants also contain excellent nutrients, especially their high crude protein $(\mathrm{CP})$ content. The $\mathrm{CP}$ content of tithonia is $22.95 \%$ (Pazla et al., 2018a). Tithonia is a shrub that is very popular with goats. 
The use of tithonia in the Ettawa Crossbreed dairy goat ration can increase consumption, digestibility, production, and quality of milk (Jamarun et al., 2020a; Arief et al., 2020). Calliandra leaves contain about 20-25\% crude protein (Djaja et al, 2007a). Calliandra has anti-nutritional substances in the form of tannins which result in low digestibility of nutrients (30-60\%), but its use in rations is still safe if given to livestock around 30-40\% (Djaja et al., 2007b). The combination of these two high-protein plants has never been studied before.

Cattle productivity is strongly influenced by the amount of feed and nutrients that can be used by cattle. However, not all of them are used, some are wasted through feces, urine, methane gas, and heat (Jamarun and Zain, 2013). Cattle absorb energy in feed especially for basic living. If there is excess energy, it will be used for production, but some of the energy absorbed in the body will be converted into body heat. Energy utilization is influenced by the quality of the intake, including the ratio of $\mathrm{CP}$ and energy or Total Digestible Nutrients (TDN). The need for feed CPTDN ratio is greater in young ruminants that are growing rapidly (Nugroho et al., 2013). The asynchronous CP and TDN ratio show optimal rumen fermentation and the feed energy used for this process to be optimal (Ginting, 2005). So, it is significant to study how much energy can be used by livestock that is fed with different proportions of $\mathrm{CP}$ and TDN. The purpose of this study was to determine the ratio of CP and TDN inefficient feed for production in Pesisir cattle, by looking at the balance of protein and energy from the feed. This research can benefit as a reference material in the use of feed composition so that the energy utilization in the feed can be optimal for production. The hypothesis of this study is "The ratio of CP and TDN of different feed has an effect on the intake, nutrient digestibility, and production performance of Pesisir cattle".

\section{MATERIALS AND METHODS}

The experimental cattle used in this research were 4 Pesisir cattle with an initial body weight of $118.13 \pm 13.13 \mathrm{~kg}$, and an age of 1.5-2 years. Guideline for ethics study of experimental animals based on the law of the Republic of Indonesia number 18 of 2009 about Animal livestock and animal husbandry. The materials used in this experiment consist of tithonia and calliandra were taken from the Lubuk Sikarah, Payo, Solok city, West Sumatera. the in vivo test was carried out in the breeder's pen, Talang Babungo, Solok Regency, West Sumatra. Analysis of the chemical composition of rations and feces was carried out based on the method of AOAC (2010). These Samples are tested in the Laboratory of Dairy Nutrition, Faculty of Animal Husbandry, Bogor Agricultural Institute, and analysis of the chemical composition of each ration constituent were carried out at the Quality Testing Center and Feed Certification, Bekasi. This study used male Pesisir cows with 4 different feed treatments with different $\mathrm{CP}$ and TDN proportions. The chemical composition of the feed ingredients for the rations and the composition of the ingredients of the treatment ration can be seen in Tables 1 and 2. Cattle are fed with complete rations with different feed ingredients compositions. The feed is given 2 times a day (07.00 AM and 3.00 PM). Water is given ad libitum. The chemical composition of the treatment rations is listed in Table 3. The equipment used is a place for feed and drinking water, a scale for weighing livestock, feed, equipment for making complete feed, a metabolic cage for feces collection, and equipment for feces collection.

Table 1: The chemical composition of the feed ingredients for the rations (\% dry matter)

\begin{tabular}{llllll}
$\begin{array}{l}\text { Chemical com- } \\
\text { position (\%) }\end{array}$ & $\begin{array}{l}\text { Native } \\
\text { grass }\end{array}$ & $\begin{array}{l}\text { Titho- Calli- } \\
\text { nia } \\
\text { andra }\end{array}$ & $\begin{array}{l}\text { Rice } \\
\text { bran }\end{array}$ & SCPLW \\
\hline Dry matter & 30.40 & 18.40 & 33.47 & 90.60 & 11.10 \\
\hline Organic matter & 89.85 & 86.61 & 94.64 & 90.80 & 86.09 \\
Ash & 10.15 & 13.39 & 5.36 & 9.20 & 13.91 \\
Crude fat & 1.63 & 5.80 & 2.83 & 15.50 & 20.00 \\
\hline Crude protein & 11.98 & 19.35 & 19.93 & 11.46 & 19.67 \\
Crude Fibre & 27.39 & 19.40 & 32.43 & 15.08 & 10.4 \\
EIWN & 48.86 & 42.06 & 39.45 & 48.76 & 63.98 \\
TDN & 55.17 & 62.87 & 60.20 & 67.85 & 62.46 \\
Ca & 0.07 & 0.99 & 0.58 & 0.07 & - \\
P & 0.09 & 0.33 & 0.23 & 0.22 & -
\end{tabular}

Note: SCPLW = Sugar cane processing liquid waste; EIWN: Extract ingredients without nitrogen.

Table 2: The ingredient composition of the treatments rations (\% dry matter).

\begin{tabular}{lllll}
$\begin{array}{l}\text { Ingredient composi- } \\
\text { tion (\%) }\end{array}$ & \multicolumn{4}{c}{ Treatment (\%) } \\
Native grass & T1 & T2 & T3 & T4 \\
Tithonia & 54.5 & 54.5 & 54.1 & 51.6 \\
Calliandra & 10 & 20 & 30 & 40 \\
\hline SCPLW & 30 & 20 & 10 & 0 \\
Rice bran & 5 & 5 & 5 & 5 \\
\hline Ultra mineral & 0 & 0 & 0.4 & 2.9 \\
\hline Salt & 0.3 & 0.3 & 0.3 & 0.3 \\
\hline
\end{tabular}

Note: SCPLW: Sugar cane processing liquid waste.

This study was designed with a Latin square design into 4 (four) complete ration treatments with four ratios of $\mathrm{CP}$ and TDN. The details of each ratio of CP: TDN are as follows: $\mathrm{T} 1=14.45 \%$ : $57.53 \%$; $\mathrm{T} 2=14.08 \%$ : $57.80 \%$; $\mathrm{T} 3=13.38 \%: 58.12 \%$ and $\mathrm{T} 4=12.59$ : $58.56 \%$. Four ratios of $\mathrm{CP}$ and TDN complete rations treatment can be seen in Table 4 . The research procedure was carried out in 4 stages including the preparation, adaptation, 
introduction, and collection stages. The preparations made were the preparation of feed, cages, and tools, as well as research Pesisir cattle. Feed preparation includes the provision of feed ingredients, analysis of nutrient content of feed ingredients, preparation of complete feeds, and manufacturing of cockpit rations. The complete way of making a complete feed is that all feed ingredients are ground, each feed ingredient is weighed according to its proportion and mixed. The cages and equipment to be used for research are prepared and cleaned. The adaptation stage is carried out by adapting livestock to the environment and research feed. The research feed was given gradually so that the cows could consume all the research feed. At this stage, deworming is also carried out so that the research cows are not affected by worm parasites. The preliminary stage is an advanced stage after the adaptation stage. The preliminary stage lasts 14 days and aims to remove food debris in the digestive tract from the previous time. At this stage, the ability of livestock to consume feed is observed. At the end of the preliminary stage, the bodyweight of the livestock is weighed. The collection stage is the final stage, feed is given as much as $4 \%$ of the bodyweight of the livestock (according to the ability of the livestock) and the distribution is done twice a day, every morning (7:00 $\mathrm{AM})$ and evening (3:00 PM) day, while drinking water is given ad libitum. Before feeding and drinking water in the morning, the remaining feed is weighed. Stool sampling for proximate analysis of each cow was carried out for 5 days. The method of collecting cattle feces is done by placed the cattle in a metabolic pen for 5 days.

Table 3: The chemical composition of the treatments rations (\% dry matter).

\begin{tabular}{lllll} 
Chemical composition & \multicolumn{4}{c}{ Treatment (\%) } \\
& T1 & T2 & T3 & T4 \\
Dry matter & 31.01 & 30.99 & 31.49 & 31.39 \\
Ash & 6.98 & 7.44 & 7.9 & 8.42 \\
Crude Protein & 14.45 & 14.08 & 13.38 & 12.59 \\
\hline Crude fat & 4.74 & 4.69 & 4.67 & 4.72 \\
Organic matter & 93.02 & 92.56 & 92.1 & 91.58 \\
EIWN & 45.89 & 46.13 & 46.39 & 46.65 \\
TDN & 57.53 & 57.80 & 58.12 & 58.56
\end{tabular}

Note: EIWN: Extract ingredients without nitrogen.

Every day, the collected feces are weighed. The method of taking the stool sample is that the feces from the collection for 5 days are mixed until evenly distributed, then $10 \%$ of the sample is taken, dried in the sun, then milled and taken to the laboratory for proximate analysis (AOAC, 2010). The data were analysed by analysis of variance. The differences that occur are tested by the Duncan multiple range test (Steel and Torrie, 2002). The method of calculating these parameters is as follows:

$$
\begin{gathered}
\text { Digestibility }(\%)=\frac{\text { Feed Intake }(\text { Kg } / \text { day })-\text { Fecal }(\text { Kg } / \text { day })}{\text { Feed Intake }(\text { Kg } / \text { day })} x 100 \% \\
\text { Feed Intake }(K g)=\text { Feed Given }(\text { Kg } / \text { day })-\text { Remaining Feed }(K g / \text { day }) \\
A D G(K g / \text { day })=\frac{\text { Final Weight }(\text { Kg })-\text { Initial Weight }(K g)}{\text { Research Time }(\text { day })} \\
\text { Feed Efficiency }(\%)=\frac{A D G(\text { kg } / \text { day })}{\text { Feed Intake }(\text { Kg } / \text { day })} x 100 \% \\
\text { Feed Conversion Ratio }=\frac{\text { Feed Intake }(\text { Kg } / \text { day })}{A D G(K g / \text { day })}
\end{gathered}
$$

\begin{tabular}{|c|c|c|c|c|}
\hline \multirow{2}{*}{$\begin{array}{l}\text { Nutritional } \\
\text { content (\%) }\end{array}$} & \multicolumn{4}{|c|}{ Treatment (\%) } \\
\hline & T1 & $\mathrm{T} 2$ & T3 & $\mathrm{T} 4$ \\
\hline Crude protein & 14.45 & 14.08 & 13.38 & 12.59 \\
\hline TDN & 57.53 & 57.80 & 58.12 & 58.56 \\
\hline
\end{tabular}

Table 4: The ratio of crude protein and TDN in the treatments rations.

\section{RESULTS AND DISCUSSION}

\section{FEed INTAKE}

The result of the study of feed intake of Pesisir cattlefed experimental diets is shown in Table 5. The results of statistical analysis showed that intake of dry matter, organic matter, and crude protein in cattle between treatments was significantly different $(\mathrm{P}<0.05)$. This means that the different $\mathrm{CP}$ and TDN Ratios in the treated feed affect the intake of dry matter, organic matter, and crude protein. This is because the composition and types of feed ingredients for the treatment rations are different. It is following the opinion of Mubarok (2008) that differences in feed ingredients can cause different feed palatability. According to Pond et al. (1995) and Reski et al. (2021), feed factors that influence intake levels to include particle size and palatability of feed ingredients.

Table 5: Effect of treatments on feed intake.

\begin{tabular}{llllll} 
Parameters & \multicolumn{4}{c}{ Treatment $(\mathrm{Kg} /$ day $)$} & SE \\
& T1 & T2 & T3 & T4 & \\
Dry matter intake & $3.52^{\mathrm{ab}}$ & $3.53^{\mathrm{ab}}$ & $3.74^{\mathrm{a}}$ & $3.23^{\mathrm{b}}$ & 0.14 \\
Organic matter intake & $3.17^{\mathrm{a}}$ & $3.14^{\mathrm{a}}$ & $3.25^{\mathrm{a}}$ & $2.66^{\mathrm{b}}$ & 0.12 \\
Crude protein intake & $2.03^{\mathrm{a}}$ & $1.96^{\mathrm{a}}$ & $2.08^{\mathrm{a}}$ & $1.58^{\mathrm{b}}$ & 0.01 \\
TDN intake & $2.15^{\mathrm{ab}}$ & $2.16^{\mathrm{ab}}$ & $2.30^{\mathrm{a}}$ & $2.00^{\mathrm{b}}$ & 0.08
\end{tabular}

a,b Significantly different a row $(\mathrm{P}<0.05)$.

The average dry matter intake of all treatments in this study was $3.23-3.74 \mathrm{~kg} / \mathrm{head} /$ day (equivalent to $2.73-2.94 \%$ of the average body weight of livestock during maintenance). The dry matter intake in the current study was higher than the dry matter intake obtained by Usman et al. (2013), that the intake of dry matter in local cattle that received a balance of CP and TDN was 13.67\%: $60 \%$ of $2.72 \mathrm{~kg}$. It 
shows that the ability to consume research cows is better, due to good feed palatability. Arora (1995) states that dry matter intake of good quality feed can reach 3.5 percent of body weight, while intake of low-quality feed is limited to only 2 percent of body weight. The higher the level of feed digestibility the better the feed consumption. Therefore, the number of nutrients used for production is increased. Table 5 shows that there was no significant difference between treatments $\mathrm{T} 1, \mathrm{~T} 2$, and $\mathrm{T} 3$ on feed intake, but there was a significant difference $(\mathrm{P}<0.05)$ between $\mathrm{T} 4$ and other treatments. T4 resulted in the lowest feed intake. The increase in the amount of tithonia from 10\% (T1), 20\% (T2) to 30\% (T3) did not affect the palatability of the rations. However, the increase in tithonia to the amount of $40 \%$ (T4) decreased feed consumption. This is because the cattle begin to taste bitter due to the influence of the phytic acid contained in tithonia. Phytic acid is one of the most abundant antinutrient substances in tithonia. Increasing the amount of tithonia in the ration will of course also increase the phytic acid levels that will be consumed by livestock. Treatments T1, T2, and T3 are a combination treatment of tithonia and calliandra. The combination does not affect the amount of feed intake statistically, the use of calliandra which is one of the legume plants can make the flow rate of feed out of the rumen faster (Kusmartono, 2008). However, from the data, treatment T3, with the combination of $30 \%$ tithonia and $10 \%$ calliandra, has the highest feed intake, meaning that these rations are very palatable for Pesisir cattle. The reduction in the amount of calliandra in the rations from $\mathrm{T} 1$ treatment to $\mathrm{T} 3$ treatment shows an increasing trend in feed intake, this is because the ratio of tannin concentrations in calliandra is also decreasing, many tannins also cause a cold sense which is not liked by livestock. The impact of tannin antinutrients on ruminants begins with the mastication process, then the tannins will bind to salivary protein so that the feed becomes less palatable and result in a decrease in feed intake.

The energy (TDN) intake of all treatments can be seen in Table 5. The results of observations on the overall feed energy intake of male Pesisir cows show a significant difference $(\mathrm{P}<0.05)$. This was possible because the intake of dry matter in all treatments was significantly different $(\mathrm{P}<0.05)$. It is following the opinion of Kearl (1982) that the need for feed energy will increase with the increasing body weight of livestock.

Nutrient digestibility factors also affect the level of feed intake, T3 ratio has the best digestibility, so that food substances are digested more quickly and used for metabolism so the stomach will empty faster, which will automatically affect livestock to return to hunger and consume more rations.

\section{NuTRIENT DigESTIBILITY}

The results of nutrient digestibility in this study can be seen in Table 6. The ratio of CP and TDN of feed to the digestibility of food substances in each treatment was significantly different $(\mathrm{P}<0.05)$. It is assumed that the digesting flow velocity and the amount of energy consumed by the treatments are also different. Arora (1995) stated that the difference in feed intake and palatability causes a difference in digesting flow velocity. Digesting flow velocity is defined as the time to eliminate $5-80 \%$ of undigested feed residue particles into feces. The difference between the number of substances consumed and those excreted in the feces does not always mean the same as the number of nutrients digested by ruminants (Arora, 1995). From the results of observations, the effect of different $\mathrm{CP}$ and TDN ratios on treated feed on digestibility of male Pesisir cattle from all treatments was significantly different $(\mathrm{P}<0.05)$. Descriptively, the highest digestibility of dry matter and organic matter was obtained in the T3 treatment $(59.50 \%$ and $59.66 \%)$, then followed by $\mathrm{T} 4(57.78 \%$ and $59.23 \%), \mathrm{T} 2$ $(57.59 \%$ and $57.44 \%)$, and $\mathrm{T} 1(50.60 \%$ and $51.11 \%)$ may be due to the consumption of crude fiber at each different treatments causing differences in feed TDN that reflect the digestibility of nutrients. Pazla (2018) stated that more consumption of crude fiber will reduce the digestibility value of the feed. The $\mathrm{CP}$ and TDN ratio of 0.25 (14.45\%: $57.53 \%)$ of feed decreased the digestibility than the ratio of 0.23 (13.38\%: 58.12\%). The results of this study are in line with the research of Purbowati et al. (2008) and Nugroho et al. (2013) which get an increase in the ratio of CP:TDN in the ratio decreases the digestibility of the feed.

\section{Table 6: Effect of treatments on nutrient digestibility.}

\begin{tabular}{llllll}
\hline Parameter & \multicolumn{4}{c}{ Treatment (\%) } & SE \\
& T1 & T2 & T3 & T4 & \\
Dry matter digestibility & $50.60^{\mathrm{b}}$ & $57.59^{\mathrm{a}}$ & $59.50^{\mathrm{a}}$ & $57.78^{\mathrm{a}}$ & 1.60 \\
\hline Organic matter digestibility & $51.11^{\mathrm{b}}$ & $57.44^{\mathrm{a}}$ & $59.66^{\mathrm{a}}$ & $59.23^{\mathrm{a}}$ & 1.25 \\
Crude protein digestibility & $59.88^{\mathrm{c}}$ & $58.08^{\mathrm{c}}$ & $75.83^{\mathrm{a}}$ & $71.42^{\mathrm{b}}$ & 0.96 \\
\hline a,b,c Significantly different a row $(\mathrm{P}<0.05)$. & & &
\end{tabular}

The productivity of ruminants is often limited by the high content of anti-nutritional compounds, including tannins (especially condensed tannin), as reported by Makkar et al. (1995). Condensed tannin compounds have properties to bind to protein, peptide, ionic group, hydroxy group, an amide group from feed presented to livestock. The dominant bond in the tannin complex; protein is a hydrogen bond that occurs between a tannin carboxyl group with a very stable peptide bond in the $\mathrm{pH}$ range $<3.0$ and $\mathrm{pH}>8.0$ (Jones and Mangan, 1977). It means that in the rumen the tannin bonds and protein are very stable. It became unstable upon arrival at the abomasum, so this potential can be used as a protein protection strategy to obtain a high protein bypass value. Thus, it is expected that tannin 
source can increase the efficiency of using feed protein as well as livestock productivity (Ningrat et al., 2018, 2019, 2020). Condensed tannin (CT) in tithonia is $0.04 \%$ DM while calliandra is 6.14\% DM (Kusmartono, 2008). Ruminants are very responsive to legumes containing tannins, especially if the positive impact is seen especially when the content does not exceed the rations (Barry, 1985). Tannin is a compound that can bind to compounds such as carbohydrates and proteins. The high level of calliandra in ration resulted in lower nutrient digestibility $(\mathrm{P}<0.05)$. It is assumed that the livestock is not sufficiently able to tolerate the anti-nutritional effect of calliandra, thereby reducing digestibility. Similarly, the opinion of Jamarun et al. (2020b) stated that antinutrients from feed ingredient will have a negative effect when it passes the optimum limit that can be tolerated by the livestock body.

Provision of concentrates containing high $\mathrm{CP}$ will activate rumen microbes that can increase proteolytic bacteria and deamination which improve the digestibility of the feed. The efficiency of microbial protein synthesis occurs when the available ammonia is followed by the availability of energy and carbon framework (Jamarun et al., 2017; Febrina et al., 2016). If the availability of ammonia is faster than carbohydrate fermentation, the ammonia used for the formation of microbial protein is inefficient. Ideal conditions for the formation of microbial protein will occur when a fermented carbohydrate source is available in line with a protein source (Christiyanto et al., 2005). Table 6 shows the rations T3 and T4 that got the composition of the rations containing rice bran showed a better clarity value than without the addition of rice bran.

Crude protein digestibility value is the percentage of crude protein consumed in the rations that are not present in feces. Crude protein digestibility is affected by the content of crude protein in the feed. Increased crude protein content in the ration will increase the rate of microbial reproduction and population rumen so that the digestibility becomes large (Jamarun et al., 2018). However, increased levels of protein rations that are not balanced with the provision of sufficient non-protein nitrogen levels cannot stimulate microbial growth in the rumen. Likewise, Teti et al. (2018) reported that the balance of protein and TDN will show efficiency optimal fermentation. Similarly, Parakkasi (1999) also stated that the addition of sources of protein cannot stimulate growth in rumen microbes without supplementation of dissolved carbohydrates. Also, Satter and Rofler (1975) state that high TDN on rations is generally more fermented than low TDN. Furthermore, Haryanto (2012) added that sync or balance between energy availability and protein in the rumen can increase microbial activity and enhance the synthesis of rumen microbial protein. In the current research, the rations of T1 treatment with a balance of CP and TDN $14.45 \%$ :
$57.53 \%$, and T2 with the balance of CP and TDN $14.08 \%$ : $57.80 \%$ results in better digestibility which is lower than the rations of T3 treatment with $\mathrm{CP}$ and TDN proportions of $13.38 \%$ : $58.12 \%$, and $\mathrm{T} 4$ with the balance of $\mathrm{CP}$ and TDN 12.59\%: 58.56\%.

\section{Production Performances}

The result of the study of average daily gain, feed conversion ratio, and feed efficiency of Pesisir cattle-fed experimental diets are shown in Table 7. Table 7 shows that the T3 treatment has the highest ADG $(\mathrm{P}<0.05)$. It increases body weight accompanied by a high consumption as well. The lowest ADG was in T1 treatments. Animal weight was always directly proportional to the level of feed intake. The higher the level of feed intake, the higher the body weight (Kartadisastra, 1997). Weight gain occurs when the feed consumed has exceeded the necessities of life, then the excess nutrients will be converted into the meat and fat tissue so that bodyweight gain becomes clearer (Williamson and Pane, 1993). Similarly, Kartadisastra (1997) demonstrated that if the amount of feed consumed is lower than their needs, the livestock will lose bodyweight.

Table 7: Effect of treatments on production performance.

\begin{tabular}{llllll} 
Parameter & \multicolumn{4}{c}{ Treatment } & \multicolumn{2}{c}{ SE } \\
& T1 & T2 & T3 & T4 & \\
ADG (Kg/day) & $0.03^{\mathrm{c}}$ & $0.21^{\mathrm{a}}$ & $0.31^{\mathrm{a}}$ & $0.08^{\mathrm{b}}$ & 0.15 \\
Feed efficiency (\%) & $0.78^{\mathrm{c}}$ & $5.94^{\mathrm{a}}$ & $8.36^{\mathrm{a}}$ & $2.47^{\mathrm{b}}$ & 4.39 \\
Feed conversion & $128.09^{\mathrm{c}}$ & $16.82^{\mathrm{a}}$ & $11.99^{\mathrm{b}}$ & $40.41^{\mathrm{b}}$ & 17.76 \\
a,b,c Significantly different a row $(\mathrm{P}<0.05)$. & &
\end{tabular}

The ADG on T3 treatment is higher than the male Pesisir cows weaning off until the age of 2 years $0.21 \mathrm{~kg} / \mathrm{head} /$ day, and the age of 3-4 years $0.12 \mathrm{~kg} /$ day, and it almost the same as the ADG from birth to weaning around 0.32 $\mathrm{kg} /$ day. The ADG in this study was lower than the Afdal and Khasrad (2006) which obtained ADG values of Pesisir cattle in the range of $0.58-0.80 \mathrm{~kg} / \mathrm{head} / \mathrm{day}$. The high value is due to the TDN value of the rations given is $68 \%$ and experimental livestock experiences a compensatory growth effect.

Dry matter intake in treatment $\mathrm{T} 4(3.23 \mathrm{Kg})$ is not as high as in treatment $\mathrm{T} 1(3.53 \mathrm{Kg})$ but this is comparably inverted when viewed from the added weight body, wherein treatment T4 the weight gain body is greater compared with body weight gain in treatment T1. Consumption of high rations does not guarantee the increase of body weight too. Likewise, Usman et al. (2013), stated that not all of livestock that consume more rations will grow higher compared to those who consume fewer rations.

The treatment of $\mathrm{T} 1 \mathrm{had}$ the highest feed conversion compared to other treatments. However, when viewed 
from weight gain, treatment $\mathrm{T} 1$ has the weight gain lowest weight gain. Conversion value on ration T1 means to produce $1 \mathrm{~kg}$ of body weight per day required 128.09 $\mathrm{kg}$ of material dry ration. Then, the conclusions showed that giving treatment $\mathrm{T} 1$ ration did not produce good feed conversion. So, it can be concluded that the feed conversion in T1 treatment is not good because the feed is consumed a lot but less effective in the meat formation. The nutritional value of feed at treatment $\mathrm{T} 1$ ratio is low. Similarly, Jamarun and Zain (2013) demonstrated that the ability of livestock in converting feed into meat is very dependent on the quality of the feed especially the content of protein, energy, and crude fiber.

The lowest rations conversion value contained in treatment T3 with dry matter intake of $3.74 \mathrm{~kg}$ and body weight up to $0.31 \mathrm{Kg}$. A good ration conversion rate is when low ration consumption can increase high body weight gain. It is presumably due to the feed intake in treatment T3 has fulfilled the physiological needs of livestock with content protein and optimal energy. Therefore, feed conversion of livestock is low as it is expressed by Maynard and Loosli (1979), the higher nutritional value in rations will influence the low conversion ratio.

Ration conversion values in treatment T2 (16.82) and T4 (40.41) are poor conversion rates because dry matter intake of $3.53 \mathrm{Kg}$ and $3.23 \mathrm{Kg}$ only increase ADG by $0.21 \mathrm{Kg}$ and $0.08 \mathrm{Kg}$. The research result indicates that the ration conversion in treatment $\mathrm{T} 3$ is lower than treatment $\mathrm{T} 2$ and T4. It can be concluded that the availability of the energy source in treatment $\mathrm{T} 3$ is more optimal for microorganisms in rumen activity that work optimally.

The best feed conversion was obtained at $\mathrm{T} 3$ treatment $(\mathrm{P}$ $<0.05)$. This condition illustrates that the quality of this T3 ration is very good and suitable for livestock and has a good palatability value. Based on Church and Pond (1995) stated that feed quality will determine feed conversion. Also, good quality feed will result in high ADG. Feed conversion is influenced by cattle breed, genetics, cow condition, age, ADG, the ability of livestock to digest feed, feed palatability, type of feed ingredients, availability of nutrients in the ration, season conditions, and management (Pazla et al., 2018b; Suyitman et al., 2020; Jusman et al., 2020). Sugiharto et al. (2004) state that the feed conversion of cows that are fed locally according to the habits of farmers on dry land is 13.6, while the ideal feed conversion for beef cattle is 9 (Tillman et al., 1991).

Treatments $\mathrm{T} 2$ and $\mathrm{T} 33$ showed the best ratio of feed efficiency so that the ADG in this treatment was also higher than treatment $\mathrm{T} 1$ and $\mathrm{T} 4$. The ratio of protein and energy in treatment T2 and T3 was very optimal in affecting the performance of rumen microbes in degrading feed, thereby increasing feed efficiency (Pazla, 2015). The low feed efficiency in treatment $\mathrm{T} 1$ and $\mathrm{T} 4$ was due to the imbalance of crude protein and TDN content in the rations. Similarly, Ariesafera (2019) states that the CP and TDN ratio in the rations is closely related to feeding efficiency. Pesisir cow will consume feed efficiently if the $\mathrm{CP}$ and TDN ratio in the rations is balanced. The feed efficiency in this study was higher than the research of Jusman et al. (2020) which was 7.78\% and lower than the research of Suyitman et al. (2020) which was $12.22 \%$. This difference is caused by the type of cow, the type of feed ingredients for the ration, and the quality of the feed used.

\section{CONCLUSIONS AND RECOMMENDATIONS}

The best ratio of protein and energy to increase feed intake, nutrient digestibility, and production performance of Pesisir cattle was $13.38 \%: 58.12 \%$ (T3). This ratio is very efficient in increasing the productivity of Pesisir cattle so that it can provide benefits for cattle breeders.

\section{ACKNOWLEDGMENTS}

This research was supported by the research and community service institutions from Andalas University with grant number is T/5/UN.16.17/PT.01.03-Pangan-RT/2020, Fiscal Year 2020. The authors would like to thank the technical assistance of the staff in the Laboratory of Dairy Nutrition, Animal Science Faculty of Bogor Agricultural Institute who had been involved in helping in the analysis.

\section{NOVELTY STATEMENT}

Research on protein and energy ratios based on Tithonia (Tithonia diversifolia) and calliandra (Calliandra calothyrsus) plants on consumption, digestibility and performance of Pesisir cattle has never been done by previous researchers. This study succeeded in finding a suitable ration formulation for fattening Pesisir cattle with the optimum ratio of TDN and crude protein to increase the productivity of Pesisir cattle.

\section{AUTHOR'S CONTRIBUTION}

Roni Pazla and Adrizal designed the study and conducted the in vivo experiment. Riesi Sriagtula performs the analysis in the laboratory. The draft article was written by Roni Pazla.

\section{CONFLICT OF INTEREST}

The authors have declared no conflict of interest. 


\section{REFERENCES}

-Ariesafera A (2019). Pengaruh pemberian level TDN (Energi) dan protein kasar silase ransum komplit berbasis limbah tebu dan limbah kubis terhadap keuntungan usaha penggemukan kerbau. Thesis, Andalas University, Padang, Indonesia.

-Afdal M, Khasrad (2006). Effect of concentrate level and the length of fattening on the growth, feed intake and feed conversion efficiency of pesisir cows in Proc. The $4^{\text {th }}$ ISTAP, pp. 335-338.

-AOAC (2010). Official Methods of Analysis. Arlington, Virginia, USA.

-Arief, Elihasridas, Sowmen S, Roza E, Pazla R, Rizqan (2018). Production and quality of Etawa raw milk using palm oil industry waste and paitan plants as an early feed.Pak.J. Nutr., 17: 399-404. https://doi.org/10.3923/pjn.2018.399.404

-Arief, Sowmen S, Rusdimansyah, Pazla R (2019). Ration digestibility based on palm oil industry byproducts, tithonia (Tithonia diversifolia) and corn waste for Etawa crossbred dairy goat. Pak. J. Nutr., 18:733-738. https://doi. org/10.3923/pjn.2019.733.738

-Arief, Sowmen S, Rusdimansyah, Pazla R, Rizqan (2020). Milk production and quality of Etawa crossbreed dairy goat given Tithonia diversifolia, corn waste, and concentrate based palm kernel cake. Biodiversitas, 21(9): 4004-4009. https://doi. org/10.13057/biodiv/d210910

-Arora SP (1995). Microbial digestion in ruminant. Indian Council of Agricultural Research. New Delhi.

- Barry TN (1985). The role of condensed tannins in the nutritional value of Lotus pedunculatus for sheep rates of body and wool growth. Br. J. Nutr., 54: 211-217. https://doi. org/10.1079/BJN19850106

- Basyar B (2021). Beef cattle farm development policies to overcome beef distribution problem in Indonesia: A literature review. Am. J. Anim. Vet. Sci., 16(1): 71-76. https://doi.org/10.3844/ajavsp.2021.71.76

- Christiyanto M, Soejono M, Utomo R, Hartadi H, Widyobroto BP (2005). The nutrient digestibility of different proteinenergy precursor rations in dairy cattle fed on a basal diet of king grass. J. Trop. Anim. Agric., 30(4): 242-247.

- Church DC, Pond WG (1995). Basic animal nutrition and feeding, $4^{\text {th }}$ ed. John Willey and Sons Inc, New York.

-Djaja WS, Kuswaryan, Tanuwiria UH (2007a). Efek substitusi konsentrat dengan daun kering kaliandra (Calliandra colothyrsus) dalam ransum sapi perah terhadap kuantitas dan kualitas susu, bobot badan dan pendapatan peternak. Prosiding Seminar Nasional Teknologi Peternakan dan Veteriner.

-Djaja WS, Kuswaryan, Tanuwiria UH (2007b). Pengaruh substitusi konsentrat daun kering kaliandra (Calliandra calothyrsus) terhadap jumlah produksi 4\% FCM, lemak, bahan kering tanpa lemak, protein dan laktosa susu sapi perah Fries Holland. J. Sains Peternakan Indonesia, 2(2): 45-48. https://doi.org/10.31186/jspi.id.2.2.45-48

- Febrina D, Jamarun N, Zain M, Khasrad (2016). The effects of P, $\mathrm{S}$, and $\mathrm{Mg}$ supplementation of oil palm fronds fermented by Phanerochayte chrysosporium on rumen fluid characteristics and microbial protein synthesis. Pak. J. Nutr., 15(3): 299304. https://doi.org/10.3923/pjn.2016.299.304

- Ginting SP (2005). Sinkronisasi degradasi protein dan energi dalam rumen untuk memaksimalkan produksi protein mikroba. Wartazoa, 15(1): 1-10.

- Hartatik T, Putra DE, Volkandari SD, Kanazawaand T, Sumadi
(2018). Genotype analysis of partial growth hormone gene (GH891 MspI) in Pesisir cattle and Simmental-Pesisir crossbred cattle. J. Indonesian Trop. Anim. Agric., 43(1): 1-8. https://doi.org/10.14710/jitaa.43.1.1-8

- Haryanto B (2012). Perkembangan penelitian nutrisi ruminansia. Wartazoa, 22(4): 169-177.

-Hendri Y (2013). Development of pesisir cattle as a local breed of West Sumatera. J. Litbang Pertanian, 32: 39-45.

-Jamarun N, Zain M (2013). Dasar nutrisi ruminansia. Jasa Surya Press, Padang, Indonesia.

-Jamarun N, Zain M, Arief, Pazla R (2017). Effects of calcium $(\mathrm{Ca})$, phosphorus $(\mathrm{p})$, and manganese $(\mathrm{mn})$ supplementation during oil palm frond fermentation by phanerochaete chrysosporium on rumen fluid characteristics and microbial protein synthesis. Pak. J. Nutr., 16(6): 393-399. https://doi. org/10.3923/pjn.2017.393.399

-Jamarun N,Zain M,Arief, Pazla R (2018). Populations of rumen microbes and the in vitro digestibility of fermented oil palm fronds in combination with tithonia (Tithonia diversifolia) and elephant grass (Pennisetum purpureum). Pak. J. Nutr., 17(1): 39-45. https://doi.org/10.3923/pjn.2018.39.45

-Jamarun N, Pazla R, Zain M, Arief (2019). Comparison of in vitro digestibility and rumen fluid characteristics between the tithonia (Tithonia diversifolia) with elephant grass (Pennisetum purpureum). IOP Conf. Ser. J. Phys. Conf. Ser. 1469(2020): 012004. https://doi.org/10.1088/17426596/1469/1/012004

- Jamarun N, Pazla R, Zain M, Arief (2020a). Milk quality of Etawa crossbred dairy goat fed a combination of fermented oilpalm fronds, Tithonia (Tithonia diversifolia), and Elephant Grass (Pennisetum Purpureum). IOP Conf. Ser. Earth Environ. Sci., 287: 012019. https://doi.org/10.1088/17551315/287/1/012019

-Jamarun N, Pazla R, Arief, Jayanegara A, Yanti G (2020b). Chemical composition and rumen fermentation profile of Mangrove leaves (Avicennia marina) from West Sumatera, Indonesia. Biodiversitas, 21(11): 5230-5236. https://doi. org/10.13057/biodiv/d211126

-Jones WT, Mangan JL (1977). Complexes of the condensed tannins of Sainfoin (Onobrychis viciifolia scop.) with fraction 1 leaf protein and with submaxillary mucoprotein, and their reversal by polyethylene glycol and $\mathrm{pH}$. J. Sci. Agric., 28: 126-136. https://doi.org/10.1002/jsfa.2740280204

-Jusman V, Arnim, Marlida Y, Pazla R (2020). Production performance and Ongole crossbred cattle receiving Saccharomyces cerevisiae supplementation. J. Res. Agric. Anim. Sci., 7: 53-58.

-Kartadisastra (1997). Penyediaan dan pengelolaan pakan ternak ruminansia. Kanisius, Yogyakarta.

-Kearl LC (1982). Nutrient requirements of ruminant in developing countries. International feedstuffs Institute, Utah.

-Kusmartono (2008). Condensed tannins in legume trees and their role in the goat diet. J. Integr. Plant Biol., 18(1): 51-62.

- Makkar HPS, Brummel M, Becker K (1995). Formation of complexes between polyvinyl pyrrolidones on polyethylene glycose and tannin and their implication in gas production and true digestibility in vivo tech. Br. J. Nutr., 73: 893-913. https://doi.org/10.1079/BJN19950095

- Maynard LA, Loosli JK, Hintz HF, Warner RE (1979). Animal nutrition, $7^{\text {th }}$ ed. Tata McGraw Hill Publishing Company Ltd, New Delhi.

- Mubarok MS (2008). Pemanfaatan energi pakan pada domba 
dengan pakan komplit dari berbagai limbah pertanian dan agroindustry. Thesis, Diponegoro University, Semarang, Indonesia.

-Ningrat RWS, Zain M, Elihasridas, Makmur M, Putri EM, Sari YC (2020). Effect of dietary supplementation based on ammoniated palm frond with saccharomyces cerevisiae and gambier leaves waste on nutrient intake and digestibility, daily gain, and methane production of Simmental cattle. Adv. Anim. Vet. Res., 8: 1325-1332. https://doi.org/10.17582/ journal.aavs/2020/8.12.1325.1332

- Ningrat RWS, Zain M, Erpomen, Suryani H (2018). Effects of supplementation of different sources of tannins on nutrient digestibility, methane production, and daily weight gain of beef cattle fed an ammoniated oil palm frond-based diet. Int. J. Zool. Res., 14: 8-13. https://doi.org/10.3923/ ijzr.2018.8.13

-Ningrat RWS, Zain M, Erpomen, Putri EM, Makmur M (2019). Effects of Leucaena leucocephala supplementation to total mixed ration based on ammoniated rice straw on fiber digestibility and rumen fermentation characteristics in vitro. Int. J. Adv. Sci. Eng. Inf. Technol., 9(3): 916-921. https:// doi.org/10.18517/ijaseit.9.3.8009

- Nugroho D, Purnomoadi A, Riyanto E (2013). The effects of different ratios of dietary crude protein and total digestible nutrients on the energy utilization of native sheep. Sains Peternakan, 11(2): 63-69. https://doi.org/10.20961/ sainspet.11.2.63-69

- Parakkasi A (1999). Ilmu Nutrisi dan Makanan Ternak Ruminansia. Universitas Indonesia Press, Jakarta.

-Pazla R(2015).Produktifitas ternak dombayang disupplementasi dengan Saccharomyces sp. dan mineral (P dan S). Magister. Thesis, Universitas Andalas, Padang, Indonesia.

- Pazla R (2018). Pemanfaatan pelepah sawit dan titonia (Tithonia diversifolia) dalam ransum kambing Peranakan Etawa untuk menunjang swasembada susu 2020. Ph.D. thesis, Andalas University, Padang, Indonesia.

- Pazla R, Jamarun N, Zain M, Arief (2018a). Microbial Protein synthesis and fermentability of fermented oil palm fronds by phanerochaete chrysosporium in combination with tithonia (Tithonia diversifolia) and elephant grass (Pennisetum purpureum). Pak. J. Nutr., 17(10): 462-470. https://doi. org/10.3923/pjn.2018.462.470

- Pazla R, Zain M, Ryanto I, Dona A (2018b). Supplementation of minerals (phosphorus and sulfur) and Saccharomyces cerevisiae in a sheep diet based on a cocoa by-product. Pak. J. Nutr., 17(7): 329-335. https://doi.org/10.3923/ pjn.2018.329.335

- Pighin D, Pazos A, Chamorro V, Paschetta F, Cunzolo S, Godoy F, Messina V, Pordomingo A, Grigioni A (2016). A contribution of beef to human health: A review of the role of the animal production systems. Sci. World J., 2016: 1-10. https://doi.org/10.1155/2016/8681491

- Pond WG, Church DC, Pond KR (1995). Basic animal nutrition and feeding. $4^{\text {th }}$ ed. John Wiley and Son, New York.

-Purbowati E, Sutrisno CI, Baliarti E, Budhi SPS, Lestariana W (2008). Complete feed energy utilization protein-energy content is different on local fattened male sheep on a feedlot basis. J. Pengembangan Peternakan Trop., 33(1): 59-65.

- Reski S, Mahata ME, Rizal Y, Pazla R (2021). Influence of brown seaweed (Turbinaria murayana) in optimizing performance and carcass quality characteristics in broiler chickens. Adv. Anim. Vet. Sci., 9(3): 407-415. https://doi. org/10.17582/journal.aavs/2021/9.3.407.415

- Satter LD, Rofler RE (1975). Nitrogen requirement and utilization in dairy cattle. J. Dairy Sci., 58: 1219-1234. https://doi.org/10.3168/jds.S0022-0302(75)84698-4

- Steel RGD, Torrie JH (2002). Principle, and procedures of statistics: A biometrical approach. $3^{\text {rd }}$ Ed. McGraw Hill Book, New York.

- Sugiharto Y, Ngadiyono N, Basuki P (2004). Produktfitas sapi Peranakan Ongole pada pola pemeliharaan system perkampungan ternak dan kandang individu di Kabupaten Bantul. J. Agrosains, 17(2): 191-202.

-Suyitman, Warly L, Rahmat A, Pazla R (2020). Digestibility and performance of beef cattle fed ammoniated palm leaves and fronds supplemented with minerals, cassava leaf meal, and their combinations. Adv. Anim. Vet. Sci., 8(9): 91-96. https://doi.org/10.17582/journal.aavs/2020/8.9.991.996

- Teti N, Latvia R, Hernaman I, Ayuningsih N, Ramdani D, Siswoyo (2018). The effect of protein to energy ratios on nutrient digestibility of female Garut Sheep's Diets. J. Interact. Technol. Pedag., 6(2): 97-101. https://doi. org/10.23960/jipt.v6i1.p97-100

-Tillman AD, Hartadi H, Reksohadiprojo S, Prawirokusumo S, Lebdosoekojo S (1991). Ilmu Makanan Ternak Dasar. Gadjah Mada University Press, Yogyakarta.

- Trisnadewi AAAS, Suryani NN, Suarna IW, Cakra IGLO (2016). Digestibility and rumen fermentation product of Crossbred Etawa Goat given Calliandra calothyrsus and Gliricidia sepium in the ration. J. Biol. Chem. Res., 33(2): 662-668.

-Usman Y, Eka MS, Nurul F (2013). Evaluasi pertambahan bobot badan sapi aceh jantan yang diberi imbangan antara hijauan dan konsentrat di balai pembibitan ternak unggul indrapuri. Agripet, 13(2): 47-52. https://doi.org/10.17969/ agripet.v13i2.819

-Williamson G, Payne WJA (1993). Pengantar Peternakan di Daerah Tropis. Gadjah Mada University Press, Yogyakarta. 